\title{
URGENSI HUKUM PERIZINAN DAN PENEGAKANNYA SEBAGAI SARANA PENCEGAHAN PENCEMARAN LINGKUNGAN HIDUP
}

\author{
Sulistyani Eka Lestari ${ }^{1}$, Hardianto Djanggih ${ }^{2}$ \\ Fakultas Hukum Universitas Sunan Bonang, Tuban, \\ J1. Dr. Wahidin Sudirohusodo No.798, Sidorejo, Kabupaten Tuban, Jawa Timur, \\ Fakultas Hukum Universitas Tompotika Luwuk Banggai, \\ Jl. Dewi Sartika, No. 67 Luwuk Banggai, Sulawesi Tengah \\ hardianto.djanggih@gmail.com
}

\begin{abstract}
Environmental problem can have an impact on the condition of the world's ecosystems. The formulation of the problem of this study is how the licensing arrangements in the environmental field and how law enforcement in the licensing field can prevent and overcome environmental pollution. The research method is normative legal research. The results showed that environmental licensing in Indonesia related to environmental issues was regulated in various types of legislation covering the fields of irrigation, mining, forestry, industry, spatial planning, land affairs, B3 waste processing, pollution control. and / or damage to the sea, fisheries, the field of conservation of living natural resources and their ecosystems as well as permits at the regional level, namely permit for disturbance (HO). In its enforcement, it can be done through means of administrative law and criminal law.
\end{abstract}

Keywords: Licensing; pollution; environment

\begin{abstract}
Abstrak
Permasalahan lingkungan dapat menimbulkan dampak terhadap kondisi ekosistem dunia. Rumusan masalah kajian ini adalah bagaimanakah pengaturan perizinan di bidang lingkungan dan bagaimanakah penegakan hukum di bidang perizinan dapat mencegah dan menanggulangi pencemaran lingkungan hidup. Metode penelitian adalah penelitian hukum normatif. Hasil penelitian menunjukkan bahwa perizinan lingkungan di Indonesia yang berkaitan dengan permasalahan lingkungan telah diatur di berbagai macam perundang-undangan yang meliputi bidang pengairan, bidang pertambangan, bidang kehutanan, bidang perindustrian, bidang penataan ruang, bidang pertanahan, bidang pengolahan limbah B3, bidang pengendalian pencemaran dan atau kerusakan laut, bidang perikanan, bidang konservasi sumber daya alam hayati dan ekosistemnya serta izin ditingkat daerah yakni izin gangguan (HO). Dalam penegakannya dapat dilakukan melalui sarana hukum admintrasi dan hukum pidana.
\end{abstract}

Kata kunci: Perizinan; Pencemaran; Lingkungan Hidup

\footnotetext{
${ }^{1}$ Dosen Fakultas Hukum Universitas Sunan Bonang, Tuban

${ }^{2}$ Dosen Fakultas Hukum Universitas Tompotika Luwuk Banggai
} 


\section{A. Pendahuluan}

Permasaahan lingkungan di negara berkembang seperti Indonesia berbeda dengan permasalahan lingkungan di negara maju. Masalah lingkungan di Indonesia disebabkan keterbelakangan pembangunan (Adharani, 2017). Berbagai masalah lingungan di Indonesia berakibat pada penurunan kualitas lingkungan baik secara langsung maupun tidak langsung. (Rochmani, 2015). Salah satu permasalahan adalah pemilihan lokasi yang tepat untuk pembuangan Lumpur panas dari kasus Lapindo Brantas supaya tidak mencemari lingkungan hingga kasus rutin setiap tahunnya yakni ekspor asap ke negara tetanggan yaitu Malaysia dan Singapura yang disebabkan pembakaran areal hutan oleh para pemegang Hak Pengelolaan Hutan (HPH)

Dalam sejarah pencemaran lingkungan di Jepang terdapat 4 (empat) kasus, yakni: kasus Itai-itai (pencemaran cadmium), kasus Minamata (Nigata), kasus Kumamoto, Kyusu (keracunan mercuri) serta kasus pencemaran udara di Yokkaichi (Rangkuti, 2000). Kasus Itai-itai telag terungkap pada tahun 1910 di kawasan Toyama City yang baru tahun 1968 para ahli dan Ministry of Health and Welfare Jepang berkesimpulan bahwa penyakit itai-itai (it hurts, it hurts) disebabkan oleh pencemaran Kadmium. Di tahun 1965 telah terjadi Minamata di Nigata yang disebabkan oleh keracunan Mercury dan sembilan tahun sebelumnya kasus Minamata terjadi di Teluk Kumamoto (Rangkuti, 2000).

Kasus pencemaran oleh limbah B-3 yang cukup terkenal adalah publikasi dari Rachel Carson pada tahun 1962 yang berjudul Silent Spring (Yulianah Trihardiningrum, 2000:4). Buku tersebut menjelaskan dijumpainya residu DDT yang masuk melalui rantai makanan pada cumi-cumi yang hidup di laut yang dalam, pada burung penguin yang hidup di laut Antartika, dan pada jaringan lemak manusia (Trihardiningrum, 2000). Publikasi Rachel Carson merupakan gambaran bagaimana keserakahan manusia di masa lampau di dalam upayanya untuk memenuhi kebutuhan hidup manusia di sector pangan. Dimana penggunaan DDT secara berlebihan yang menyebabkan terakumulasinya DDT di dalam tubuh manusia maupun hewan.

Permasalahan lingkungan di atas merupakan gambaran sekilas dari perusakan lingkungan yang terjadi di luar Indonesia, Indonesia tentunya juga terjadi kasus-kasus pencemaran terhadap lingkungan dimana kasus-kasus tersebut sebagian besar belum dapat ditangani secara optimal. Upaya untuk menangani segala macam permasalahan lingkungan di Indonesia masih sangat minim baik dari segi ilmu maupun kesadaran dari para pihak yang terkait secara langsung maupun tidak dengan lingkungan. Dari segi ilmu tentunya kita dapat memahami cara-cara yang lazim digunakan masyarakat didalam memanfaatkan alam Indonesia, antara lain cara yang digunakan dalam membuka lahan untuk lahan pertanian maupun perkebunan, cara menangkap ikan, cara membuang sampah, maupun kegiatankegiatan yang memiliki dampak pencemaran dan atau perusakan terhadap lingkungan hidup. Kemudian dari segi kesadaran para pihak, pola piker masyarakat Indonesia pada umumnya yang hanya memikirkan kepentingan pribadi maupun sesaat masih sangat mendominasi di benak masing-masing. Hal ini didukung dengan pemahaman bahwa alam ini adalah milik kita bukannya titipan anak cucu kita, dimana kita bisa lihat dan cermati bahwa ekspor asap yang rutin terjadi tiap tahunnya merupakan sebagai bukti kurangnya kepedulian dari sektor swasta terhadap lingkungan, sebagai contoh para pemegang HPH dimana mereka membakar puluhan bahkan ratusan ribu hektar hutan tiap tahunnya dalam rangka membuka lahan untuk pertanian maupun perkebunan. 
Segala macam permasalahan di atas tentunya merugikan kepentingan rakyat banyak, hal ini dapat kita lihat dan cermati bahwa untuk pengaturan pengelolaan lingkugan hidup yang baik dan sehat diatur dalam berbagai macam peraturan perundangan, antara lain Pasal $28 \mathrm{H}$ ayat (1) Undang-undang Dasar 1945 yang memuat ketentuan sebagai berikut:

"Setiap orang berhak hidup sejahtera lahir batin, bertempat tinggal, dan mendapatkan lingkungan hidup yang baik dan sehat serta berhak memperoleh pelayanan kesehatan".

Kemudian ketentuan dalam Pasal 5 ayat (1) Undang-undang Nomor 32 Tahun 2009 tentang Perlindungan Dan pengelolaan Lingkungan Hidup yang memuat sebagai berikut:

"Setiap orang mempunyai hak yang sama atas lingkungan hidup yang baik dan sehat".

Dan Pasal 9 ayat (3) Undang-undang Nomor 39 Tahun 1999 tentang Hak Asasi Manusia, yang memuat ketentuan sebagai berikut:

"Setiap orang berhak atas lingkungan hidup yang baik dan sehat".

Dengan adanya berbagai macam peraturan perundang-undangan diatas tentunya tiap-tiap manusia Indonesia berhak atas lingkungan yang baik dan sehat sebagaimana dijamin oleh Pancasila dan UUD NRI 1945 (Triana, 2014). Hal ini merupakan kebutuhan primer atau hak dasar bagi setiap orang. Namun dengan melihat perkembangan kondisi lingkungan terakhir ini, dimana banyak terjadi kasuskasus lingkungan yang terkesan diabaikan begitu saja dan tidak adanya peran serta aktif baik pemerintah maupun masyarakat dalam memperjuangkan hak-hak dasar mereka atas lingkungan yang baik dan sehat, tentunya hak tiap warga negara untuk memperoleh lingkungan yang baik dans ehat tidak dapat terpenuhi secara optimal. Di Indonesia selama ini belum terlihat wujud nyata / konkret yang menyangkut masalah penegakan hukum lingkungan, hal ini dapat dilihat dari banyaknya kasus pencemaran, antara lain kasus Buyat oleh PT. Newmont, illegal logging, pembakaran hutan, PT. Freeport, PT. Lapindo Brantas, dan lain-lain yang tidak mampu diselesaikan dan ditangani secara optimal oleh pemerintah selaku pihak yang berwenang.

Belum lagi permasalahanpermasalahan lain yang terjadi di kota Surabaya, misalnya masalah sampah yang dibuang oleh masyarakat di Kalimas dan Kali Surabaya, drainase yang kurang baik karena timbunan sampah di saluransaluran air dan lain-lain.

Salah satu instrument yang dapat digunakan sebagai upaya penegakan hukum lingkungan adalah dari segi perizinan. Hal ini dikarenakan bahwa sebenarnya fungsi dari izin untuk mencegah maupun untuk menanggulangi permasalahan lingkungan. Hal ini dikarenakan segala jenis bentuk usaha maupun industri meemrlukan izin untuk dapat didirikan. Hal ini bisa dilihat dari ketentuan Pasal 18 ayat 1 Undang-undang Nomor 32 Tahun 2009 tentang Perlindungan Dan pengelolaan Lingkungan Hidup, yakni:

Setiap usaha dan/atau kegiatan yang menimbulkan dampak besar dan penting terhadap lingkungan hidup wajib memiliki analisis mengenai dampak lingkungan hidup untuk memperoleh izin melakukan usaha dan/atau kegiatan.

Berbagai permasalahan dihadapi dalam sistem perizinan di Indonesia dewasa ini salah satunya adalah dimana satu kegiatan yang dilakukan oleh seseorang/badan hukum memerlukan izin secara terpisah-pisah dengan instansi yang mengeluarkan izin berbeda-beda pula tergantung izin yang dibutuhkan oleh suatu usaha dan/atau kegiatan yang dilakukan. Sebagai contoh pengusaha yang bermaksud mendirikan kegiatan usaha 
tertentu lazimnya memerlukan izin $\mathrm{HO}$, izin usaha industri, izin mendirikan bangunan, izin lokasi, izin pembuangan limbah cair yang kesemuanya merupakan wewenang dari instansi yang ebrbeda. Hal ini menunjukkan bahwa prosedur perizinan di Indonesia umumnya bersifat sektoral sentries (Rangkuti, 2000).

Sejarah pengaturan izin di Indonesia diawali dengan pengaturan masalah perizinan lingkungan yang diatur didalam Hinder Ordonantie (HO) atau disebut dengan Ordonansi Gangguan Stb. 1926 No.226 dengan judul Niuwe Bepalingen motrent het Oprichten van Inrichtingen, welke Gevaar, Schade of Hinder Kunnen Veroorzaken, yang mulai berlaku tanggap 1 Agustus 1926, diubah dan ditambah dengan Stb. 1927 No.449, Stb. 1940 No.14 dan 450 (Siti Sundari Rangkuti, 2000:143). Didalam pengaturan Pasal $5 \mathrm{HO}$ terdapat pengaturan sederhana mengenai peran serta masyarakat didalam bentuk pernyataan pendapat / keberantan (inspraak) sebelum permohonan izin diputuskan, namun dalam kenyataannya tidak pernah diterapkan. Hal ini sebenarnya merupakan ide yang brilian namun didalam kenyataannya proses pemberian izin tidak pernah melibatkan masyarakat karena proses pengambilan Keputusan Tata Usaha Negara (besichikking) ditempuh dengan cara kesepakatan antara individu yakni antara instansi yang berwenang dengan peminta izin.

Didalam perkembangan pengaturan perizinan lingkungan ternyata menemukan berbagai macam perizinan yang berdiri sendiri-sendiri, misalnya Undang-undang Nomor 5 Tahun 1984 tentang Perindustrian yang mengatur perizinan industri, Peraturan Pemerintah Nomor 85 Tahun 1999 tentang Pengelolaan Limbah Berbahaya dan Beracun, Peraturan Pemerintah Nomor 82 tahun 2001 tentang Pengelolaan Kualitas Air dan Pengendalian Pencemaran Air, Peraturan Pemerintah Nomor 41 Tahun 1999 tentang Pengendalian Pencemaran Udara.
Kesemuanya menunjukkan bahwa perlunya sebuah instrument hukum yang mampu mengatur dan mengakomodasikan segala keseluruhan peraturan perundangundangan diatas dalam suatu system "izin lingkungan" kedalam satu bentuk Undangundang Pengelolaan Lingkungan Hidup yang bersifat komprehensif (Rangkuti, 2000), dimana elemen-elemen undangundang tersebut hendaklah mengatur tentang: (Rangkuti, 2000).

1. Sistem perizinan lingkungan untuk instalasi yang mencakup semua jenis pencemaran lingkungan.

2. Wewenang untuk menetapkan baku mutu ambient, effluent, dan proses produksi terhadap jenis pencemaran lingkungan.

3. Prosedur perizinan, termasuk peran serta masyarakat dan akses terhadap informasi.

4. Ketentuan tentang perlindungan hukum administrasi (banding).

5. Ketentuan tentang pengawasan dan penegakan hukum lingkungan administrative dan kepidanaan.

Dari perumusan kelima hal diatas berdampak kepada kewenangan sebuah instansi. Hal ini dikarenakan didalam melakukan pengelolaan lingkungan yang mutlak adalah tentang kewenangan pengelolaan lingkungan, wacana implikatifnya adalah harus jelas instansi mana yang memiliki kewenangan melakukan pengelolaan lingkungan, termasuk pengelolaan lingkungan di daerah (Wijoyo, 2005). Hal ini juga tak lepas dari kedudukan Menteri Negara Lingkungan Hidup (MENLH) sebagai "Menteri Negara" yang tidak memimpin departemen pemerintahan, yang berarti tidak mempunyai "portefeuile", yaitu wewenang administrative structural (Rangkuti, 2000). Wewenang memberi izin lingkungan hanya dimiliki seorang Menteri Lingkungan yang memimpin departemen pemerintahan. 


\section{Rumusan Masalah}

Dari latar belakang masalah tersebut, dirumuskan masalah yang akan dikaji dalam penulisan ini yakni sebagai berikut:

a. Bagaimanakah pengaturan perizinan di bidang lingkungan sebagai upaya untuk mencegah pencemaran dan/atau perusakan lingkungan hidup?

b. Bagaimanakah penegakan hukum di bidang perizinan dapat mencegah dan menanggulangi pencemaran dan/atau perusakan lingkungan hidup?

\section{B. Metode Penelitian}

Untuk mengkaji tulisan ini, metode penelitian yang digunakan adalah penelitian hukum normatif. Oleh karena itu, maka mtode pendekatan yang digunakan adalah pendekatan perundangundangan (statute approach) dan pendekatan konsep (conceptual approach). Pendekatan ini untuk mengkaji asas-asas hukum, norma-norma hukum, dan konsepkonsep hukum. Adapun sumber dan jenis bahan hukum adalah bahan hokum kepustakaan, yakni baham hukum primer, bahan hukum sekunder dan bahan hokum tersier. Bahan-bahan hukum tersebut dikaji secara deskriptif-kualitatif serta ditarik kesimpulan secara dedukti-induktif.

\section{Hasil dan Pembahasan}

\section{Pengaturan Perizinan Di Bidang Lingkungan Di Indonesia}

Izin Sebagai Instrumen Administrasi Dalam Pencegahan Pencemaran di Bidang Lingkungan

Pemahamanan tentang Izin merupakan suatu persetujuan dari penguasa berdasarkan undang-undang atau peraturan pemerintah, untuk dalam keadaan tertentu menyimpang dari ketentuan larangan perundangan (B.J.M. Ten Berge dan N.M. Spelt,). Perizinan merupakan salah satu bentuk dari campur tangan pemerintah (Wibisana, 2017).

Izin mempunyai 2 (Dua) pengertian yakni izin dalam arti sempit dan izin dalam arti pelepasan atau pembebasan / dispensasi (Wibisana, 2017). Izin dalam arti sempit mempunyai tujuan untuk mengatur tindakan-tindakan yang oleh pembuat undang-undang tidak seluruhnya dianggap tercela, namun dimana ia mengingkan dapat melakukan pengawasan sekedarnya (Wibisana, 2017). Pada intinya pengertian izin dalam arti sempit adalah suatu tindakan yang dilarang, terkecuali diperkenankan. Sedangkan pengertian izin sebagai pelepasan atau pembebasan (dispensasi) adalah izin memang dimaksudkan sebagai pengecualian yang sungguh-sungguh, pelepasan adalah pengecualian atas larangan sebagai aturan umum (Wibisana, 2017).

Kaitannya dengan permasalahan lingkungan, izin merupakan salah satu upaya pencegahan terhadap kerusakan lingkungan hidup adalah melalui kebijakan sistem perizinan lingkungan (Rhitti dan Pudyatmoko, 2016). Izin lingkungan dan persyaratannya harus dibuat berdasarkan ukuran-ukuran yuridis yang memperhitungkan keadaan individual kegiatan industri yang memiliki dampak pada langkah-langkah pengelolaan lingkungan hidup (Wijoyo, 2012:98).

Di dalam penggunaan izin sebagai sarana administrasi dalam pencegahan pencemaran di bidang lingkungan tentunya harus memenuhi beberapa aspek terlebih dahulu, yakni (Wijoyo, 2012):

a. Tujuan dari penerbitan izin.

b. Dasar hukum / legitimasi yang meliputi wewenang, substansi, dan prosedur.

c. Konformitas hukum.

Ketiga hal diatas merupakan syaratsyarat dalam menerbitkan izin, karena keputusan pemberian izin akan berkaitan langsung maupun tidak langsung kepada masyarakat sebagai pelaksanaan dari izin.

a. Tujuan Izin.

Tujuan izin adalah sebagai instrument dalam mengendalikan aktivitas masyarakat dengan cara mempengaruhi para warga agar mau mengikuti cara-cara yang dianjurkan guna mencapai suatu tujuan konkrit (Wijoyo, 2012). Selain itu tentunya 
penguasa memiliki motif-motif atau fungsi dengan dikeluarkannya izin, dimana motif tersebut antara lain (Wijoyo, 2012):

1) Keinginan mengarahkan (mengendalikan - sturen) aktivitasaktivitas tertentu (misalnya izin bangunan).

2) Mencegah bahaya bagi lingkungan (izin-izin lingkungan).

3) Keinginan melindungi obyek-obyek tertentu (izin penebangan, izin membongkar monument).

4) Hendak membagi benda yang sedikit (izin penghunian).

5) Pengarahan dengan menyeleksi orang-orang dan aktivitas-aktivitas (izin berdasarkan "Drank-en Horecawet", dimana pengurus harus memenuhi syarat-syarat tertentu, SIM).

b. Dasar Hukum.

Izin adalah salah satu instrument yang paling banyak digunakan didalam ruang lingkup hukum administrasi. Pemerintah menggunakan izin sebagai sarana yuridis untuk mengatur/mengendalikan

perilaku/tingkah laku masyarakatnya, oleh karena itu sebagai tindakan pemerintah izin yang merupakan suatu Keputusan Tata Usaha Negara (KTUN) harus mempunyai dasar hukum atau unsure legitimasi didalam menerbitkan izin yang lebih dikenal dengan istilah asas keabsahan, dimana meliputi 3 hal yakni wewenang, substansi dan prosedur (Hadjon, 1992).

Dengan demikian maka izin harus memenuhi ketiga syarat keabsahan seperti yang telah disebutkan diatas, oleh karena itu berikut ini akan dijelaskan ketiga asas diatas.

a. Wewenang.

Ruang lingkup penggunaan wewenang itu memiliki tiga elemen, yaitu (Djamiati, 2004):

1) Mengatur.

Kewenangan mengatur berkaitan dengan tugas pemerintah dalam menjalankan fungsi mengatur.
Sesuai dengan fungsi tersebut kewenangan pemerintah mengeluarkan izin digunakan untuk mengatur tingkah laku warga agar aktivitas warga tidak mengganggu warga lain.

2) Mengontrol.

Kewenangan melakukan control terhadap kehidupan masyarakat sangat berkaitan dengan tugas pemerintah yang berhubungan dengan tugas mengatur. Dimana pengontrolan kepada masyarakat dilakukan melalui pengaturan dengan mengadakan pembatasanpembatasan tertentu kepada aktivitas masyarakat di bidang social, ekonomi, maupun bidang politik. Kewenangan mengontrol dimaksudkan agar masyarakat dapat lebih terarah dalam melakukan aktivitas, sehingga tidak menyimpang dari ketentuanketentuan larangan atau perintah yang diberikan oleh pemerintah berdasarkan peraturan hukum yang ada. Dengan demikian dalam menetapkan izin sebagai sarana yang digunakan untuk mengendalikan aktivitas masyarakat tidak hanya berhenti dalam menetapkan izin saja, tetapi pemerintah memiliki kewenangan untuk melakukan kewenangan mengontrol agar izin dalam melaksanakan sesuai dengan ketentuan persetujuan tersebut.

3) Pemberian sanksi / penegakan hukum.

Kewenangan untuk memberikan sanksi sangat dominant dalam bidang hukum administrasi, oleh karena itu tidak ada manfaatnya bagi pejabat pemerintah dilengkapi kewenangan mengatur dan kewenangan mengontrol tanpa ada kewenangan untuk menerapkan sanksi. Didalam menjalankan fungsi mengatur diperlukan saran "pemaksa", agar aturan-aturan 
hukum yang dimiliki pemerintah dipatuhi oleh warga masyarakat.

Wewenang sebagai salah satu asas keabsahan bagi pemerintah dalam melakukan tindakan pemerintah merupakan konsep inti dalam Hukum Tata Negara dan Hukum Administrasi sebagai hukum publik. Wewenang lazimnya dideskripsikan sebagai kekuatan hukum/rechtsmacht, sehingga wewenang senantiasa berkaitan dengan kekuasaan negara. Wewenang sekurang-kurangnya terdiri atas 3 komponen, yaitu: pengaruh, dasar hukum dan konformitas hokum (Hadjon, 1990).

Komponen pengaruh berarti penggunaan wewenang dimaksudkan untuk mengendalikan perilaku subyek hukum. Dalam pelaksanaan wewenang untuk menetapkan digunakan sebagai sarana mempengaruhi masyarakat untuk menjalankan cara-cara yang ditetapkan pemerintah agar mencapai tujuan tertentu berupa pengendalian terhadap aktivitas seseorang (Tim Pengajar, 2006).

Komponen dasar hukum bermakna setiap wewenang harus selalu dapat ditunjuk dasar hukumnya sebagai realisasi dari asas legalitas. Dengan demikian setiap kewenangan untuk menetapkan izin harus diatur dalam peraturan perundangundangan tertentu, yaitu dalam figure hukum yang mendapat persetujuan wakil rakyat (UU dan Perda) karena izin merupakan pembatasan terhadap hak asasi manusia yang digunakan sebagai sarana pengendalian (Tim Pengajar, 2006:21).

Komponen konformitas hukum beresensi adanya standart wewenang, baik standart umum untuk semua jenis wewenang maupun standart khusus bagi jenis wewenang tertentu. Standart ini dimaksudkan agar dalam penetapan izin, pemerintah memiliki pedoman dan ukuran, sehingga pemerintah tidak akan melakukan tindakan yang sewenangwenang (Tim Pengajar, 2006).

Kewenangan yang dimiliki oleh badan administrasi atau pejabat dalam melakukan tindakan nyata, mengadakan peraturan ataupun mengeluarkan keputusan dilandasi oleh kewenangan yang diperoleh secara "atribusi", "delegasi", maupun "mandat" (Djamiati, 2004). Suatu atribusi menunjuk kepada kewenanganyanga asli atas dasar ketentuan hukum tata negara (Djamiati, 2004). Delegasi menegaskan suatu perlimpahan wewenang kepada badan pemerintahan yang lain(Tatiek Sri Djamiati, 2004:ibid) Sedangkan pada mandat tidak terjadi pelimpahan ataupun dalam arti pemberian kewenangan, akan tetapi pejabat yang diberi mandat oleh pejabat lain bertindak atas nama pemberi mandat (mandator) (Djamiati, 2004).

Izin merupakan bentuk kewenangan yang berupa pemberian keputusan oleh badan administrasi atau pejabat. Menurut P.M. Hadjon, menyatakan bahwa kewenangan membuat keputusan (izin) hanya dapat diperoleh dengan 2 (dua) cara yaitu dengan atribusi dan delegasi (Hadjon, 1990).

Apabila berbicara tentang kewenangan tentunya kita juga tidak dapat melupakan kewenangan pemerintah di daerah dalam menetapkan izin. Hal ini tidak lepas dari adanya Undang-undang Nomor 32 Tahun 2004 tentang Pemerintah Daerah dimana ada izin yang ditangani oleh Pemerintah Kabupaten / Kota. Kewenangan Pemerintah Kabupaten / Kota diatur dalam Pasal 10 (2) Undangundang No.32 Tahun 2004 tentang Pemerintah Daerah sebagai berikut:

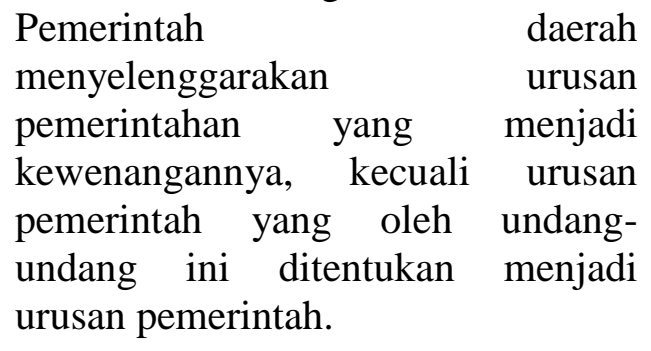

Urusan pemerintah di daerah dijalankan berdasarkan asas desentralisasi, dekonsentrasi dan tugas pembantuan. Desentralisasi adalah penyerahan wewenang Pemerintah oleh pemerintah kepada daerah otonom untuk mengatur dan 
mengurus urusan pemerintah dalam system Negara Kesatuan Republik Indonesia. Dekonsentrasi adalah pelimpahan wewenang Pemerintahan oleh pemerintah kepada Gubernur sebagai wakil pemerintah dan/atau kepada instansi vertical di wilayah tertentu, sedangkan Tugas pembantuan adalah penugasan Pemerintah kepada daerah dan/atau desa dari pemerintah provinsi kepada kabupaten/kota kepada desa untuk melaksanakan tugas tertentu.

Atas dasar ketiga asas tersebut kewenangan pemberian izin dibedakan atas (Hadjon, 1990):

1. Izin atas dasar kewenangan otonomi (desentralisasi).

2. Izin atas dasar pelimpahan kewenangan dari pemerintah kepada Gubernur dan/atau instansi vertical (dekonsentrasi).

3. Izin sebagai pelaksanaan tugas pembantuan.

b. Prosedur.

Prosedur penetapan izin diatur di dalam peraturan perundang-undangan yang mengatur masing-masing izin. Seperti kita ketahui bahwa perizinan di bidang lingkungan bersifat sektoral sehingga tidak terdapat acuan yang jelas ataupun kodifikasi bagaimana tata cara penetapan izin. Namun secara teoritis terdapat asasasas umum prosedur penetapan izin yang meliputi (Hadjon, 1990):

1. Permohonan.

2. Acara persiapan dan peran serta.

3. Pemberian keputusan.

4. Susunan keputusan.

Berikut ini penjelasan terhadap masing-masing asas-asas umum dalam prosedur penetapan izin, yakni:

1. Permohonan.

Permohonan merupakan langkah awal dalam perizinan, dan permohonan adalah permintaan yang berkepentingan akan suatu keputusan (Hadjon, 1990), sehingga setiap penetapan izin harus didasarkan pada permohonan dari pihak
p-ISSN : 2086-2695, e-ISSN : 2527-4716

yang berkepentingan atas dikeluarkannya keputusan (izin).

2. cara persiapan dan peran serta masyarakat (inspraak).

Kedudukan izin sebagai suatu Keputusan Tata Usaha Negara (KTUN) adalah bersifat keputusan bebas. Hal ini mengandung pengertian bahwa dalam penetapannya, izin tidak hanya didasarkan pada norma hukum administrasi yang tertulis, yaitu peraturan perundang-undangan tetapi juga didasarkan pada norma hukum yang tidak tertulis yaitu Asas-asas Umum Pemerintahan Yang Baik (AUPB). Salah satu asasnya adalah asas kecermatan (ketelitian). Sebagai salah satu asas dalam AUPB asas kecermatan mempunyai kedudukan yang penting dalam penetapan izin (Tim Pengajar, 2006).

Acara persiapan ditujukan kepada tiap-tiap permohonan izin. Hal ini dimaksudkan bahwa pemerintah sebagai instansi pemberi keputusan memberikan kesempatan bagi masyarakat dan instansi lain yang terkait untuk memberikan masukan atau pertimbangan terhadap permohonan izin. Atas adanya masukan-masukan tersebut pemerintah dapat menggunakannya sebagai bahan pertimbangan untuk menetapkan izin agar izin tersbeut tidak menimbulkan hal-hal yang buruk dan merugikan siapapun (Tim Pengajar, 2006).

Peran serta masyarakat (inspraak) dapat dilakukan dengan berbagai macam cara antara lain musyawarah, dengar pendapat, maupun memberikan masukan secara tertulis kepada instansi yang menetapkan izin atau cara-cara lain yang telah ditentukan.

3. Pemberian keputusan.

Keputusan pemerintah atas permohonan izin yang diajukan oleh pihak yang berkepentingan terdiri dari 3 (Tiga) jenis, yaitu (Tim Pengajar, 2006:ibid).:

1. Permohonan tidak dapat diterima. 
2. Penolakan izin.

3. Pemberian izin.

Keputusan yang menyatakan permohonan tidak dapat diterima dikarenakan bukan karena substansi izin melainkan karena tidak lengkapnya persyaratan administasi. Keputusan permohonan tidak dapat diterima disebabkan oleh beberapa hal sebagai berikut:

a. Permohonan bukan diajukan oleh yang berkepentingan.

b. Permohonan diajukan setelah lewat jangka waktu yang ditetapkan.

c. Permohonan diajukan bukan kepada instansi yang berwenang.

Penolakan izin terjadi apabila ada keberatan-keberatan mengenai isi terhadap pemberian izin. Dalam hal ini asas-asas yang menjadi dasar penolakan terhadap suatu izin harus dicantumkan dalam keputusan penolakan.

Pemberian izin merupakan keputusan yang mengabulkan permohonan izin. Pemberian izin harus didasarkan pertimbangan yang baik oleh pemerintah dengan memperhatikan peraturan perundang-undangan dan UAPB. Hal terpenting dalam prosedur penerbitan izin adalah pengumuman yang dapat diketahui baik oleh pihak yang berkepentingan maupun masyarakat baik keputusan itu berupa penolakan maupun pemberian izin, pengumuman ini memberikan kesempatan bagi pihak yang berkepentingan maupun masyarakat untuk melakukan upaya perlindungan hukum.

4. Susunan keputusan perizinan.

Bagian terpenting dari keputusan perizinan adalah diktum, uraian isi mufakat yang diberikan dengan izin dan ketentuan-ketentuan, pembatasanpembatasan atau syarat-syarat yang dikaitkan pada izin. Disamping itu, keputusan seringpula memuat pemberian alasan, dimana ketentuanketentuan undang-undang yang diterapkan, penetapan fakta oleh organ pemerintah dan pertimbanganpertimbangan hukum yang dilakukan oleh organ pemerintahan dan pertimbangan-pertimbangan hukum yang dilakukan organ dicantumkan.

c. Substansi

Pengertian substansi sebagai salah satu bagian dari asas keabsahan dalam pemberian izin adalah isi atau materi dari suatu izin yang diajukan oleh pihak yang berkepentingan. Substansi sangat berkaitan erat dengan pemberian keputusan dalam penerbitan izin, hal ini dapat apabila substansi dari permohonan tidak bertentangan dengan peraturan perundangundangan yang terkait dan AUPB maka izin akan dikabulkan sedangkan apabila substansi bertentangan maka izin akan ditolak.

\section{Pengaturan Perizinan di Bidang Lingkungan}

Pengaturan perizinan yang berkaitan dengan masalah lingkungan sangatlah beragam dan bersifat sektoral sehingga penjelasan dalam sub bab ini akan dipilahpilah sesuai dengan bidangnya masingmasing.

\section{a. Bidang Pengairan}

Undang-undang Nomor 11 Tahun 1974 tentang Pengairan tertanggal 26 Desember 1974 jo. Undang-undang Nomor 7 Tahun 2004 tentang Sumber Daya Air. Disamping peraturan tersebut juga terdapat Peraturan Pemerintah Nomor 82 Tahun 2001 tentang Pengelolaan Kualitas Air dan Pengendalian Pencemaran Air. Kewenangan mengenai pengendalian terhadap pencemaran air diatur dalam Pasal 20 Peraturan Pemerintah Nomor 82 tahun 2001 tentang Pengelolaan Kualitas Air dan Pengendalian Pencemaran Air, yang menyebutkan bahwa:

Pemerintah dan Pemerintah Propinsi, Pemerintah Kabupaten / Kota sesuai dengan kewenangan amsing-masing dalam rangka pengendalian pencemaran air pada sumber air berwenang: 
1) Menetapkan daya tampung beban pencemaran.

2) Melakukan inventarisasi dan identifikasi sumber pencemaran.

3) Menetapkan persyaratan air limbah untuk aplikasi pada tanah.

4) Menetapkan persyaratan pembuangan air limbah ke air atau sumber air.

5) Memantau kualitas air pada sumber air.

6) Memantau faktor lain yang menyebabkan perubahan mutu air.

\section{b. Bidang Pertambangan}

Peraturan perundangan-undangan di bidang pertambangan sangatlah beragam, antara lain:

1) Undang-undang Nomor 11 Tahun 1967 tentang Ketentuan-Ketentuan Pokok Pertambangan tertanggal 2 Desember 1967. Kewenangan mengenai pemberian izin pertambangan diatur dalam Pasal 15 ayat 3 Undang-undang Nomor 11 Tahun 1967 tentang KetentuanKetentuan Pokok Pertambangan yang menyebutkan bahwa:

Kuasa Pertambangan diberikan dengan Keputusan Menteri Dalam Keputusan Menteri itu dapat diberikan ketentuan-ketentuan khususnya disamping apa yang telah dalam Peraturan Pemerintah yang termaksud dalam ayat (2) pasal ini.

2) Undang-undang Nomor 22 Tahun 2001 tentang Minyak dan Gas Bumi tertanggal 23 November 2001. Kewenangan mengenai pengelolaan minyak dan gas bumi diatur dalam Pasal 4 Undang-undang Nomor 22 Tahun 2001 tentang Minyak dan Gas Bumi, yang menyebutkan bahwa :

a) Minyak dan Gas Bumi sebagai sumber daya alam yang tak terbarukan yang terkandung di Wilayah Hukum Pertambangan Indonesia merupakan kekayaan nasional yang dikuasai oleh negara.

$\begin{array}{ccr}\text { b) Penguasaan } & \text { oleh } & \text { Negara } \\ \text { sebagaimana } & \text { dimaksud } & \text { dalam }\end{array}$ ayat (1) diselenggarakan oleh Pemerintah sebagai pemegang kuasa pertambangan.

c) Peemrintah selaku pemegang kuasa pertambangan membentuk Badan pelaksana sebagaimana diatur dalam Pasal 1 angka 23.

3) Undang-undang Nomor 27 Tahun 2003 tentang Panas bumi tertanggal 22 Oktober 2003. Kewenangan pengelolaan panas bumi diatur dalam Pasal 5,6, dan 7. Pada Pasal 5 diatur kewenangan pengelolaan oleh Pemerintah, sedangkan pada Pasal 6 merupakan kewenangan pemerintah Propinsi sedangkan Pasal 7 mengatur kewenangan Pemerintah Kabupaten / Kota sebagai contoh mengenai kewenangan dapat kita lihat pada Pasal 7 Undang-undang Nomor 27 Tahun 2003 tentang Panas Bumi yang menyebutkan bahwa:

1. Kewenangan Kabupaten / Kota dalam pengelolaan pertambangan Panas Bumi meliputi:

a. Pembuatan peraturan perundang-undangan di daerah di bidang pertambangan Panas Bumi di kabupaten / kota.

b. Pembinaan dan pengawasan pertambangan Panas Bumi di kabupaten / kota.

c. Pemberian izin dan pengawasan pertambangan Panas Bumi di kabupaten / kota.

d. Pengelolaan informasi geologi dan potensi Panas Bumi di kabupaten / kota.

e. Inventarisasi dan penyusunan neraca sumber daya dan cadangan Panas Bumi di kabupaten / kota.

f. Pemberdayaan masyarakat di dalam ataupun di sekitar wilayah kerja di kabupaten / kota.

2. Kewenangan kabupaten / kota sebagaimana dimaksud pada ayat 
(1) dilaksanakan sesuai dengan ketentuan peraturan perundangundangan yang berlaku.

\section{c. Bidang Kehutanan}

Pengaturan izin di bidang kehutanan diatur dalam Undang-undang Nomor 41 Tahun 1999 jo. Undang-undang Nomor 19 Tahun 2004 tentang Penetapan Peraturan Pemerintah Pengganti Undang-undang Nomor 1 Tahun 2004 tentang Perubahan Atas Undang-undang Nomor 41 Tahun 1999 tentang Kehutanan menjadi undangundang. Kewenangan pengelolaan hutan diatur dalam Pasal 4 ayat 2 UU Kehutanan yang menyebutkan bahwa:

Penguasaan hutan oleh Negara sebagaimana dimaksud pada ayat (1) memberi wewenang kepada pemerintah untuk:

1) Mengatur dan mengurus segala sesuatu yang berkaitan dengan hutan, kawasan hutan, dan hasil hutan.

2) Menetapkan status wilayah tertentu sebagai kawasan hutan atau kawasan hutan sebagai bukan kawasan hutan.

3) Mengatur dan menetapkan hubungan-hubungan hukum antara orang dengan hutan, serta mengatur perbuatan-perbuatan hukum mengenai kehutanan.

\section{d. Bidang Perindustrian}

Pengaturan izin diatur dalam Undangundang Nomor 5 Tahun 1984 tentang Perindustrian dan Peraturan Pemerintah Nomor 13 Tahun 1995 tentang Izin Usaha Industri. Mengenai kewenangan pemerintah dalam mengatur masalah industri diatur dalam pasal 8 Peraturan Pemerintah Nomor 13 Tahun 1995 tentang Izin Usaha Industri yang menyebutkan bahwa:

Pemerintah melakukan pengaturan, pembinaan, dan pengembangan bidang usaha industri secara seimbang, terpadu, dan terarah untuk memperkooh struktur industri nasional pada setiap tahap perkembangan industri.
Dan Pasal 12 Peraturan Pemerintah Nomor 13 Tahun 1995 tentang Izin Usaha Industri yang menyebutkan bahwa:

Untuk mendorong pengembangan cabang-cabang industri dan jenisjenis industri tertentu di dalam negeri, Pemerintah dapat memberikan kemudahan dan/atau perlindungan yang diperlukan.

\section{e. Bidang Penataan Ruang}

Peraturan perundangan yang mengatur masalah penataan ruang adalah Undangundang Nomor 24 Tahun 1992 tentang Penataan Ruang. Undang-undang ini memiliki peran yang cukup vital mengingat peranan undang-undang ini dalam membentuk perencanaan suatu wilayah baik di tingkat nasional, Propinsi maupun Kabupaten/Kotamadya. Undangundang ini juga mempunyai peran cukup penting karena penataan ruang suatu daerah sangat berpengaruh terhadap kondisi ekologis maupun lingkungan di suatu daerah. Hal ini diatur dalam Pasal 22 ayat 4 Undang-undang Nomor 24 Tahun 1992 tentang Penataan Ruang yang menyebutkan bahwa:

Rencana Tata Ruang Wilayah
Kabupaten/Kotamadya Daerah
Tingkat II menjadi dasar untuk
peenrbitan perizinan lokasi
pembangunan.

\section{f. Bidang Pertanahan}

Undang-undang yang berkaitan dengan masalah tanah adalah Undang-undang Nomor 5 Tahun 1960 tentang PeraturanPeraturan Dasar Pokok Agraria. Masalah pertanahan apabila dikaitkan dengan perizinan di bidang lingkungan maka sangatlah erat hal ini dapat dilihat dengan adanya peraturan pemerintah yang secara khusus mengatur masalah izin lokasi, yakni : Peraturan Menteri Negara Agraria/Kepala badan Usaha Pertanahan Nasional Nomor 2 Tahun 1999 tentang Izin Lokasi dimana izin lokasi selalu terkait dengan izin di bidang penataan ruang, dan merupakan satu rangkaian dengan bidang perindustrian dalam perolehan tanah untuk kepentingan 
pembangunan industri. Hubungan antara izin lokasi dengan bidang penataan ruang maupun dengan perindustrian diatur dalam Pasal 3 Peraturan Menteri Negara Agraria / Kepala Badan Pertanahan Nasional Nomor 2 Tahun 1999 tentang Izin Lokasi, yang menyebutkan:

Tanah yang ditunjuk dalam Izin lokasi adalah tanah yang menurut Rencana Tata Ruang Wilayah yang berlaku diperuntukkan bagi penggunaan yang sesuai dengan rencana penanaman modal yang akan dilaksanakan oleh perusahaan menurut persetujuan penanaman modal yang dipunyainya.

Sedangkan mengenai kewenangan dalam menerbitkan izin lokasi diatur dalam Pasal 7 ayat 1 Peraturan Menter Negara Agraria / Kepala Badan Pertanahan Nasional Nomor 2 Tahun 1999 tentang Izin Lokasi yang menyebutkan bahwa:

Ketentuan lebih lanjut mengenai tata cara pemberian izin lokasi ditetapkan oleh Bupati/Walikotamadya atau, untuk Daerah Khusus Ibukota Jakarta, oleh Gubernur kepala Daerah Khusus Ibukota Jakarta.

\section{g. Bidang Pengelolaan (Limbah) Bahan Berbahaya dan Beracun}

Pengaturan pengelolaan limbah B3 diatur dalam (Rahmadi, 2003):

1) Undang-undang Nomor 14 Tahun 1992 tentang Lalu Lintas dan Angkutan Jalan.

2) Peraturan Pemerintah Nomor 18 Tahun 1999 jo. Peraturan pemerintah Nomor 85 Tahun 1999 tentang Pengelolaan Limbah Bahan Berbahaya dan Beracun.

3) Peraturan Pemerintah Nomor 74 Tahun 2001 tentang Pengelolaan Bahan Berbahaya dan Beracun.

4) Peraturan Pemerintah Nomor 64 Tahun 2000 tentang Perizinan Pemanfaatan Tenaga Nuklir.
5) Peraturan Pemerintah Nomor 41 Tahun 1993 tentang Angkutan Jalan.

Kemudian diatur dalam Pasal 18 Peraturan Pemerintah Nomor 41 Tahun 1999 tentang Pengendalian Pencemaran dara yang menyebutkan bahwa:

1) Pelaksanaan operasional pengendalian pencemaran udara di daerah dilakukan oleh Bupati / Walikotamadya Kepala Daerah Tingkat II.

2) Pelaksanaan koordinasi operasional pengendalian pencemaran udara di daerah dilakukan oleh Gubernur.

3) Kebijaksaan operasional pengendalian pencemaran udara sebagaimana dimaksud pada ayat (1) dapat ditinjau kembali setelah 5 (lima) tahun.

Hal ini juga diaturdalam Pasal 19 Peraturan Pemerintah Nomor 41 Tahun 1999 tentang Pengendalian Pencemaran Udara yang menyebutkan bahwa:

1) Dalam rangka penyusunan dan pelaksanaan operasional pengendalian pencemaran udara di daerah segaimana dimaksud dalam Pasal 18 ayat (1), daerah menyusun dan menetapkan program kerja daerah di bidang pengendalian pencemaran udara.

2) Ketentuan mengenai pedoman penyusunan dan pelaksanaan operasional pengendalian pencemaran udara di daerah sebagaimana dimaksud pada ayat (1) ditetapkanoleh Kepala instansi yang bertanggungjawab.

\section{Penegakan Hukum Administrasi Terhadap Perizinan Dibidang Lingkungan}

Penegakan hukum lingkungan di Indonesia mencakup penataan dan penindakan (compliance and enforcement) (Kim, 2013). Apabila kita berbicara mengenai penegakan hukum administrative tentunya kita membahas sarana yang dapat digunakan dalam 
penegakan hukum administrasi. Menurut

P.M. Hadjon menyatakan bahwa sarana penegakan hukum administrasi berisi (Hadjon, 1996:337):

1. Pengawasan.

2. Penerapan sanksi pemerintahan.

Menurut J.B.J.M. Teu Berge menyatakan bahwa instrument penegakan hukum administrasi meliputi:

1. Pengawasan.

2. Penerapan sanksi merupakan langkah represif untuk memaksakan kepatuhan.

Ruang lingkup penegakan hukum administrative meliputi:

1. Preventif.

Meliputi pengawasan, untuk mencegah agar jangan sampai terjadi pelanggaran, yang mempunyai tujuan ketaatan peraturan.

2. Represif.

Penerapan sanksi, untuk menghentikan pelanggaran dan mengembalikan pada situasi sebelum terjadinya pelanggaran norma-norma hukum.

Konsep-konsep dasar penegakan hukum administrasi, yaitu meliputi (Hadjon, 1990):

1. Legitimasi.

Meliputi dengan $\begin{aligned} & \text { wewenang } \\ & \text { pengawasan dan }\end{aligned}$ wewenang
menerapkan sanksi.

2. Instrumen Yuridis.

Berkaitan dengan jenis-jenis sanksi administrasi dan prosedur menerapkan sanksi.

3. Norma Hukum Administrasi.

Norma hukum tertulis dan AUPB

4. Kumulasi Sanksi.

Penerapan sanksi secara bersama-sama antara sanksi hukum administrasi dengan hukum lainnya dapat terjadi, yakni kumulasi internal dan kumulasi eksternal.

Apabila kita berbicara mengenai konsep-konsep dasar penegakan hukum administrasi tentunya tidak lupa kita membahas mengenai instrument yuridis dalam hukum administrasi yang dapat digunakan dalam rangka penegakan hukum administrasi. Sanksi-sanksi dalam hukum administrasi yang khas, antara lain (Hadjon, 1990):

a. Bestruursdwang (paksaan pemerintah).

b. Penarikan kembali keputusan (ketetapan) yang menguntungkan (izin, pembayaran, subsidi).

c. Pengenaan denda administrative.

d. Pengenaan uang paksa oleh pemerintah (dwangsom).

Sedangkan sifat-sifat dari sanksi administrasi antara lain (Hadjon, 1990):

1. Tujuan pelaksanaan sanksi adalah perbuatan pelanggarannya.

2. Memiliki sifat "reparatoir" artinya memulihkan pada keadaan semula.

3. Prosedur pelaksanaan sanksi dilakukan secara langsung oleh pejabat tata usaha negara tanpa melalui prosedur peradilan.

Mengenai penjelasan terhadap jenisjenis sanksi adminitrasi adalah sebagai berikut:

a. Paksaan Pemerintah.

Rumusan mengenai pengertian paksaan pemerintah dirumuskan sebagai tindakan nyata atas biaya para pelanggar guna menyingkirkan, mencegah, melakukan, atau mengembalikan pada keadaan semula apa yang telah dilakukan atau sedang dilakukan yang bertentangan peraturan perundang-undangan tertentu (P.M. Hadjon, 1990:ibid).

Paksaan pemerintah tidak selalu diartikan dengan paksaan dalam bentuk kekuatan fisik. Namun jika diperlukan dapat digunakan paksaan kekuatan fisik. Pelaksanaan paksaan pemerintah adalah suatu wewenang, bukan suatu kewajiban. Kewenangan untuk melakukan paksaan pemerintah adalah kewenangan bebas (vrijebevoeigheid). Prosedur pelaksanaan paksaan pemerintah wajib didahului oleh dengan peringatan secara lisan maupun tertulis, jika tetap tidak memperhatikan peringatan tersebut maka pengenaan paksaan pemerintah baru dilaksanakan. 
b. Penarikan kembali keputusan (ketetapan) yang menguntungkan (izin, pembayaran, subsidi) selaku sanksi.

Terdapat dua hal terhadapnya suatu keputusan (ketetapan) yang menguntungkan dapat ditarik kembali sebagai sanksi (Hadjon, 1990):

a. Yang berkepentingan tidak mematuhi pembatasan-pembatasan, syarat-syarat atau ketentuan peraturan perundang-undangan yang dikaitkan pada izin, subsidi atau pembayaran.

b. Yang berkepentingan pada waktu mengajukan permohonan untuk mendapat izin, subsidi, atau pembayaran telah memberikan data yang sedemikian tidak benar atau tidak lengkap, sehingga apabila data itu diberikan secara benar atau lengkap maka keputusan akan berlainan (misalnya: penolakan izin, dsb). Pencabutan sebagai sanksi administrasi merupakan wewenang yang melekat pada wewenang menetapkan KTUN (misalnya: pemberian izin). Sifatnya pencabutan sebagai sanksi bisa bersifat reparatoir juga bisa condemnatoir.

c. Pengenaan denda administrasi.

Denda administrasi berbeda dengan uang paksa, denda administrasi tidak lebih dari sekedar reaksi terhadap pelanggaran norma, yang ditujukan untuk menambah hukuman yang pasti, terutama denda administrasi yang terdapat dalam hukum pajak.

d. Uang paksa.

Uang paksa dikenakan sebagai alternative untuk paksaan pemerintah yang berarti sebagai sanksi subsidair dan dianggap sebagai sanksi reparatoir. Dalam praktek hukum perizinan sanksi ini tidak pernah diterapkan, karena tidak dibuat dalam peraturan perundang-undangan.

Kajian sanksi pidana di dalam hukum pidana merupakan bagian khusus dari hukum pidana. Sanksi pidana merupakan tindakan yang dapat ditujukan terhadap pelaku tindak pidana (kejahatan dan pelanggaran). Tindakan yang terdapat di dalam sanksi pidana berupa hukuman. Jika seseorang melakukan tidnak pidana pencurian, maka pelaku mendapat hukuman pidana yakni sanksi pidana atas perbuatan pencurian tersebut.

Sanksi pidana memiliki sifat penjera dan derita terhadap pelaku tindak pidana (kejahatan dan pelanggaran). Sifat penjera dan derita adalah tujuan utama dari hukum pidana, sehingga dalam sanksi pidanapun juga meliputi sifat tersebut. Oleh karena itu, sanksi pidana memiliki cirri khas yang berlainan dari sanksi-sanksi bidang ilmu hukum lainnya (sanksi administrasi dan sanksi perdata). Didalam sanksi pidana terdapat kaidah hukum yang bersifat melarang. Jika kaidah hukum tersebut dilanggar dengan sengaja (dolus) maupun oleh karena kealpaan (culpa), maka penegakan sanksi pidana tidaklah dapat dikesampingkan dan tidak ada pengecualian. Segala perbuatan dapatlah dipertanggungjawabkan dengan pengenaan sanksi pidana terhadap pelaku tindak pidana (kejahatan dan pelanggaran).

Berbagai peraturan perundangundangan telah diterbitkan oleh badan legislative dan eksekutif di Indonesia. Dari peraturan perundang-undangan yang diterbitkan, masing-masing mencantumkan ketentuan pidana sebagai alat untuk menegakkan norma-norma hukum yang mempunyai sifat mengatur dan melarang kemudian dilanggar dan disimpangi secara sengaja maupun karena kealpaan.

Pandangan atas penerapan sanksi pidana menjadi acuan kerangka interpretasi hukum pidana dalam menanggulangi tindak pidana. Setiap perbuatan pidana baik kejahatan maupun pelanggaran dapatlah dikenai sanksi pidana atas perbuatannya. Sanksi pidana menjadi hal terpenting di dalam aturan hukum yang memiliki sifat represif di dalam penegakannya. 
Kitab Undang-undang Hukum Pidana (KUHP) memuat berbagai jenis sanksi pidana. Dalam Pasal 10 Kitab Undangundang hukum Pidana (KUHP) disebutkan bahwa pidana terdiri atas:

a. Pidana pokok:

1. Pidana mati.

2. Pidana penjara.

3. Pidana kurungan.

4. Pidana denda.

5. Pidana tutupan.

b. Pidana tambahan:

1. Pencabutan hak-hak tertentu.

2. Perampasan barang-barang tertentu.

3. Pengumuman putusan hakim.

Dari pengaturan 2 (dua) macam sanksi pidana di atas, dalam peraturan perundangundangan tidaklah dicantumkan semua. Peraturan perundang-undangan sering menggunakan jenis sanksi pidana penjara, pidana kurungan, dan pidana denda. Hal ini disesuaikan dengan perbuatan pidana yang dilakukan. Semakin banyak peraturan perundang-undangan diterbitkan, maka semakin banyak pula pengaturan sanksi pidananya di dalam ketentuan pidana pada peraturan perundang-undangan tersebut.

Mengenai penegakan hukum izin dari segi hukum pidana dapat dikatakan bahwa sasaran upaya penegakan hukum sudah tepat karena telah mencapai tahap penyidikan, semoga pada pemeriksaan ke depannya instansi peradilan dalam hal ini PN maupun PT mampu membuat sebuah keputusan yang bijak dan membuat jera meskipun penerapan sanksi pidana merupakan ultimum remedium. Meskipun demikian penerapan sanksi pidana tetap tidak dapat memulihkan kondisi lingkungan yang telah dicemari ke keadaan semula sebelum tercemar. Hal ini menandakan betapa lemahnya pemahaman para konseptor peraturan perundangundangan tentang pentingnya fungsi lingkungan dalam menunjang kehidupan manusia. Karena berapapun besarnya denda yang harus dibayar ataupun pidana penjara sekalipun tidak dapat mengganti besarnya biaya kerusakan serta memulihkan kondisi lingkungan yang telah rusak akibat pelanggaran tersebut.

Hal ini juga menunjukkan bahwa para pembuat peraturan tidak dapat berpikir secara multidispliner mengenai pentingnya keberadaan sebuah izin terhadap dampak yang nantinya timbul akibat izin tersebut diberikan. Meskipun kita telah mengenal piranti AMDAL maupun UPL dan UKL namun tetap saja keberadaan mereka dapat dengan mudah disimpangi demi mencapai tujuan yang diinginkan yakni sebuah izin.

Hal ini semakin kentara apabila kita melihat pada saat ini di tiap Kabupaten / Kota fungsi izin sebagai sarana pencegahan dan pengendalian telah berubah menjadi sarana untuk mencari uang. Hal ini ditegaskan dengan adanya Undang-undang Nomor 18 Tahun 1997 jo. Undang-undang Nomor 34 Tahun 2000 tentang Pajak dan Retribusi Daerah, dimana pada asal 157 Undang-undang Nomor 32 Tahun 2004 tentang Pemerintahan daerah menyatakan bahwa Pendapatan Asli Daerah (PAD) berasal dari:

1. Hasil pajak daerah.

2. Hasil retribusi daerah.

3. Hasil pengelolaan kekayaan daerah yang dipisahkan.

4. Lain-lain PAD yang sah.

Fungsi dan peran dari pajak dan retribusi daerah sebagai salah satu sumber PAD, ditegaskan kembali melalui Peraturan Pemerintah Nomor 65 Tahun 2001 tentang Pajak daerah dan Peraturan Pemerintah Nomor 66 Tahun 2001 tentang Retribusi Daerah.

Dalam Peraturan Pemerintah Nomor 66 Tahun 2001 tentang Retribusi Daerah telah ditetapkan bahwa Retribusi Daerah dibedakan dalam 3 jenis, yaitu:

a. Retribusi jasa usaha.

b. Retribusi jasa umum.

c. Retribusi perizinan tertentu.

Menurut Pasal 3 Peraturan Pemerintah Nomor 66 Tahun 2001 tentang Retribusi Daerah, maka izin-izin yang dapat dipungut retribusi adalah:

1. Izin Mendirikan Bangunan (IMB). 
2. Izin Tempat Penjualan Minuman Beralkohol.

3. Izin Gangguan (HO).

4. Izin Trayek.

Dengan demikian salah satu bentuk retribusi yang dipungut di daerah adalah retribusi perizinan tertentu yang jenis perizinannya telah ditetapkan dalam Pasal 3 Peraturan Pemerintah Nomor 66 Tahun 2001 tentang Retribusi Daerah. Hal ini menjadi dasar bagi pemerintah Kabupaten/Kota untuk menggali uang dari diterbitkannya izin. Gejala yang terjadi adalah pemerintah daerah sibuk mengatur tentang berbagai macam izin yang dikenakan retribusi dan bahkan tidak terkesan rasional karena mengenakan biaya retribusi yang tinggi. Dengan demikian telah terjadi perubahan fungsi dari izin sebagai instrument yuridis pencegahan menjadi sarana untuk pemenuhan PAD bagi daerah-daerah.

\section{Simpulan}

Perizinan lingkungan di Indonesia yang berkaitan dengan permasalahan lingkungan telah diatur di berbagai macam perundang-undangan yang ebrsifat sektoral dimana bidang-bidang yang terkait dengan pengaturan izin meliputi bidang pengairan, bidang pertambangan, bidang kehutanan, bidang perindustrian, bidang penataan ruang, bidang pertanahan, bidang pengolahan limbah B3, bidang pengendalian pencemaran dan atau kerusakan laut, bidang perikanan, bidang konservasi sumber daya alam hayati dan ekosistemnya serta izin ditingkat daerah yakni izin gangguan (HO). Upaya penegakan hukum dalam pengaturan izin dibedakan dalam 2 (dua) upaya yakni penegakan hukum administrasi dan penegakan hukum pidana. Dalam penegakan hukum administrasi mempunyai tujuan untuk memulihkan keadaan. Mengenai wewenang penegakan hukum dimiliki oleh pemberi izin dalam hal ini tergantung instansi pada masingmasing bidang, serta instrument yang digunakan berupa pengawasan dan sanksi pengawasan dan sanksi administrasi. Pada instrument pengawasan masing-masing peraturan perundangan yang terkait mengatur masalah pengawasan didalamnya, sedangkan mengenai bentuk pengaturan dari instrument sanksi administrasi berupa peringatan, pembekuan izin sementara, paksaan pemerintah dan uang paksa belum banyak tercantum pada tiap-tiap peraturan perizinan di bidang lingkungan. Pada penegakan hukum pidana mempunyai tujuan untuk memberikan derita/nestapa, mengenai kewenangan tetap berada pada pemberi izin dan selalu bekerja sama dengan kepolisian. Sedangkan instrument yang digunakan adalah sanksi pidana yang umumnya berupa pidana kurungan, pidana penjara dan pengenaan denda.

\section{DAFTAR PUSTAKA}

Adharani, Y. (2017). Penataan dan Penegakan Lingkungan Pada Pembangunan Infrastruktur dalam Mewujudkan Pembangunan Berkelanjutan, (Studi Kasus Pembangunan PLTU II Di Kecamatan Mundu Kabupaten Cirebon), Padjajaran Jurnal Ilmu Hukum, 4 (4), 61-83.

Djamiati, T. S. (2004). Prinsip Izin Usaha Industri di Indonesia, Disertasi, 2004, Surabaya: Pascasarjana Universitas Arilangga.

Hadjon, P. M. 1992). Pengatar Hukum Administrasi Indonesia, Cetakan ke-8, Yogyakarta: Gadjah Mada University Press.

Hadjon, P. M. (1996). Penegakan Administrasi Dalam Pengelolaan Lingkungan Hidup, dalam Butir-Butir Gagasan Penyelenggaraan Hukum dan Pemerintahan Yang Layak, Cetakan I, Bandung: Citra Aditiya Bakti.

Kim, S. W. (2013). Kebijakan Hukum Pidana Dalam Upaya Penegakan Hukum Lingkungan Hidup, Jurnal Dinamika Hukum, 13 (3), 415-427. 
Rahmadi, T. (2003). Hukum Pengelolaan Bahan Berbahaya dan Beracun, Cetakan I, Surabaya: Airlangga University.

Rangkuti, S. S. (2000). Hukum Lingkungan dan Kebijaksanaan Lingkungan Nasional, edisi kedua, Surabaya: Airlangga University Press.

Rhitti H. dan Y. Sri Pudyatmoko. (2016) Kebijakan Perizinan Lingkungan Hidup Di Daerah Istimewa Yogyakarta, Jurnal Mimbar Hukum, 28 (2), 263-276.

Rochmani. (2015). Perlindungan Hak Atas Lingkungan Hidup Yang Baik dan Sehat Di Era Globalisasi, Jurnal Masalah-Masalah Hukum, 44 (1), 1825.

Tim Pengajar (2006). Hukum Perijinan, Surabaya: Fakultas Hukum Universitas Airlangga.

Triana, N (2014). Pendekatan Ekoregion Dalam Sistem Hukum Pengelolaan Sumber Daya Air Sungai di Era Otonomi Daerah, Pandecta, Research Law Journal, 9 (2), 154-168.

Trihardiningrum, Y. (2000). Pengelolaan Limbah Bahan Berbahaya dan Beracun (B3), Surabaya: Buku Ajar Jurusan Tehnik Lingkungan Fakultas Tehnik Sipil dan Perencanaan Institut Teknologi Sepuluh Nopember.

Wibisana, A. G. (2017). Campur Tangan Pemerintah Dalam Pengelolaan Lingkungan: Sebuah Penelusuran Teoretis Berdasarkan Analisis Ekonomi Atas Hukum (Economic Analysis Of Law), Jurnal Hukum Dan Pembangunan, 47(2), 151-182.

Wijoyo, S. (2005). Kelembagaan Pengelolaan Lingkungan di Daerah, Surabaya: Airlangga University Press.

Wijoyo, S. (2012). Persyaratan Perizinan Lingkungan Dan Arti Pentingnya Bagi Upaya Pengelolaan Lingkungan Di Indonesa, Jurnal Yuridika, 27 (2), 97110. 